\title{
Excerpts from Focus Group Discussions: Bangladesh
}

\author{
Naomi Hossain
}

\begin{abstract}
The focus groups on which these excerpts are based were conducted in 2007 as part of research by the BRAC Research and Evaluation Division with Save the Children UK Bangladesh support into perceptions and practices of child labour, conducted in Nilphamari and Karail in Dhaka, Bangladesh. Further details of the research are available in S. Tariquzzaman and E. Kaiser (2008) Employers' Perceptions of Changing Child Labour Practices in Bangladesh, BRAC Research and Evaluation Division monograph 35, Dhaka: BRAC-RED (www.bracresearch.org/monographs/Monograph_35\%20.pdf).
\end{abstract}

What do I want to be when I grow up?

A girl from our village had a better job in a garment since many days. Watching her, my wish is, after growing up, will do work in garments after completing study.

(FGD with rural girls, 11-17 years)

After growing up, if I be an employer, I will not engage any children for work rather adults only.

Because children feel shock if they have to do work. I will give them scope for study.

(FGD with rural girls, 11-17 years)

It's not fair to think something big about future. We have to do hard work in our whole life. Our life is like the below story:

A man carrying two pot full of oil was going towards the market and thinking that he will buy hen by selling the oil. Hen will give many chicken and eggs. He will buy a cow by selling those chicken and eggs. As a result he will get much money. After then, he will marry. His wife will cook for him. If any day it is late to cook, he will beat his wife so much. By imagining like that, he threw the oil pot to the ground and his dream merge up with the ground immediately.

(FGD with rural boys, 11-17 years)

My father says, 'When grown up you should run own business. You should do something independently.' So I have decided to. I shall establish a restaurant business. I shall employ children but will never behave what they dislike. When they will enjoy leave I myself do their task.

(FGD with urban boys, 11-17 years)

The rich people's boys go around wearing sunglass as a fashion. Can't I wish it? When grown up I shall take mud digging task. More money will be earned. I will buy land, will marry and go around with own style.

(FGD with rural boys, 6-10 years) 